\title{
Design and testing of a microchannel reactor for the PROX reaction
}

S. Cruz ${ }^{1}$, O. Sanz ${ }^{1}$, R. Poyato ${ }^{1}$, O.H. Laguna ${ }^{1 *}$, F. J. Echave ${ }^{2}$, L.C. Almeida ${ }^{2}$, M.A. Centeno ${ }^{1}$, G. Arzamendi ${ }^{3}$, L.M. Gandia ${ }^{3}$, E.F. Souza-Aguiar ${ }^{4}$, M. Montes ${ }^{2}$, J.A. Odriozola ${ }^{1}$

${ }^{1}$ Inst. of Material Sciences of Seville, CSIC - Universidad de Sevilla. Avda. Américo Vespuccio 49, 41092 Seville, Spain

${ }^{2}$ Dept. Appl. Chemistry, Universitiy of the Basque Country, Paseo Manuel Lardizábal 3, 20018, San Sebastián, Spain

${ }^{3}$ Public University of Navarre, Campus de Arrosadía, s/n, E-31006 Pamplona, Spain

${ }^{4}$ Petrobras, Rio de Janeiro, Brazil

${ }^{*}$ Corresponding author: Oscar Hernando Laguna Espitia

e-mail address: oscarh@icmse.csic.es

Telephone: +34 954489501 Ext. $9221 \quad$ Fax: +34 954460665

\begin{abstract}
The different steps for manufacturing a microchannel reactor for the PROX reaction are discussed. Transient Liquid Phase bonding (TLP) using a Ni-B-Si amorphous melt spun is used for joining micromilled Al-alloyed ferritic stainless steel plates followed by recrystallization at $1200^{\circ} \mathrm{C}$ for 5 hours. $\mathrm{A} \mathrm{CuO}{ }^{-}-\mathrm{CeO}_{2}$ catalyst synthesized by the coprecipitation method was washcoated on the microchannel block resulting in a homogenous 20-30 $\mu \mathrm{m}$ thick layer. The catalytic activity for CO-PROX reaction is similar in both the powder catalyst and the microchannel coated reactor but the selectivity is higher in the microchannel reactor.
\end{abstract}

\section{Keywords}

1) Microchannel reactor

2) CO-PROX

3) $\mathrm{CuO}_{x}-\mathrm{CeO}_{2}$
4) Transient Liquid Phase bonding
5) Al-alloyed ferritic stainless steel 


\section{Introduction}

The widespread use of portable electric and electronic devices increases the need for efficient autonomous power supplies that replace the currently predominant battery technology. The use of common fuels/chemicals (hydrocarbons or alcohols) as energy sources is a promising alternative when combined with the recent developments in microchannel reactor technology. The high power density, rapid start-up time, and low-temperature operation of PEMFC make these devices as the most promising for powering up electric or electronic devices. However, an essential requirement for the reformate-fed PEMFC is the removal of $\mathrm{CO}$ from the $\mathrm{H}_{2}$ stream after the reforming and watergas shift (WGS) reactions. After the WGS units the CO content of the hydrogen streams may vary between ca. 0.5 and 2 vol. \% being, therefore, mandatory clean-up units for the removal of $\mathrm{CO}$ to trace level. Preferential $\mathrm{CO}$ oxidation (CO-PROX) is among the preferred technologies for small-scale fuel processor applications [1]. CO-PROX reactions allow reducing CO contents from $1 \%$ in the feed to the ppm level.

When using PEMFCs for portable or automotive applications packed-bed reactors have several drawbacks such as pressure drop within catalyst layer, temperature gradients, and hot spot due to the high exothermicity of the oxidations of $\mathrm{CO}$ and $\mathrm{H}_{2}$. Microreactors have the advantages of fast response time, easy integration, and small footprint, which are ideal for portable power systems. In addition, enhanced mass and heat transport properties are also widely recognized as advantages of microreactors [2-6]. In addition to this, recent studies of simulated CO-PROX reactions have shown that the reverse water-gas-shift side reaction is favoured in the case of packed bed reactors with respect to thin catalytic films deposited on microchannel walls [4]. Therefore, CO-PROX units based on microchannel reactors have been reported as part of integrated fuel processors in a wide power range [6-9].

Different catalytic systems and reactor designs have been proposed for the $\mathrm{CO}$ PROX reaction. In a recent study Bion et al. [10] review the performances of noble metals (including $\mathrm{Pt}, \mathrm{Ru}, \mathrm{Rh}, \mathrm{Pd}$ and $\mathrm{Au}$ ) and transition metal oxides catalysts and compare the advantages and drawbacks for each type of catalysts in terms of activity and selectivity including the influence of the 
presence of $\mathrm{CO}_{2}$ and $\mathrm{H}_{2} \mathrm{O}$ in the reactants flow. They conclude that $\mathrm{CuO}-\mathrm{CeO}_{2}$ catalysts are very attractive for industrial applications since their excellent performances, stability and low cost compared to noble metal-based catalysts.

Dudfield et al. [11, 12] operated a compact fin heat-exchanger reactor containing $2.5 \% \mathrm{Pt}-\mathrm{Ru}$ catalyst in the CO-PROX reaction. Using a two-stage configuration this unit allowed reductions in the $\mathrm{CO}$ concentrations down to 15 ppm. Silicon wafers [13] or austenitic stainless steel plates [14, 15] were used for building microchannel reactors for the PROX reaction. Hwang et al. [16] studied the reaction over a silicon-based microreactor coated with a $\mathrm{Pt} / \mathrm{Al}_{2} \mathrm{O}_{3}$ catalyst, yielding $99.4 \%$ CO conversion. Kim et al. $[15,17]$ obtained CO outlet concentration below $50 \mathrm{ppm}$ at $\mathrm{O}_{2} / \mathrm{CO}$ ratio of 2.5 by using a 13-layered microchannel reactor built by stacking chemically etched stainless steel plates coated with a Pt-Co/ $/ \mathrm{Al}_{2} \mathrm{O}_{3}$ catalyst. Despite most of the work on CO-PROX in microreactors has been carried out using noble metal based catalysts a few insights on copper based catalysts have been reported. Snytnikov et al. [18] compared a $5 \mathrm{wt} . \% \mathrm{Cu} / \mathrm{CeO}_{2}$ catalyst in both fixed bed and microchannel reactors with the latter exhibiting higher conversion and selectivity. This catalyst allowed the reduction of the $\mathrm{CO}$ concentration from 1 vol.\% to $10 \mathrm{ppm}$. Kim et al. [15] compared a $\mathrm{CuO} / \mathrm{CeO}_{2}$ coated microreactor with a Pt-Co coated microreactor showing better selectivities in the CO-PROX reaction for the copper-based catalyst.

In the present work, we provide a description of the different steps required for manufacturing a microchannel reactor for the CO-PROX reaction. The reactor is tested using conventional $\mathrm{CuO}_{x} / \mathrm{CeO}_{2}$ catalysts and the results compared with those obtained for powdered catalysts.

\section{Materials and methods}

\subsection{Catalyst preparation}

The $\mathrm{CuO}_{\mathrm{x}}-\mathrm{CeO}_{2}$ catalyst was prepared by the coprecipitation method. The amount necessary for preparing a $0,5 \mathrm{M}$ solution of $\mathrm{Cu}\left(\mathrm{NO}_{3}\right)_{2} \cdot 3 \mathrm{H}_{2} \mathrm{O}$ and $\mathrm{Ce}\left(\mathrm{NO}_{3}\right)_{3} \cdot 6 \mathrm{H}_{2} \mathrm{O}$ were mixed, under vigorous stirring, to get a 9:1 $\mathrm{Ce}(\mathrm{OH})_{3}: \mathrm{Cu}(\mathrm{OH})_{2}$ weight ratio. After homogenizing the system, a $\mathrm{NaOH}$ solution $(2 \mathrm{M})$ was added dropwise until a stable $\mathrm{pH}$ of 9 . The precipitate was 
filtered and washed with distilled water in order to remove the $\mathrm{Na}^{+}$and $\mathrm{NO}_{3}{ }^{-}$ ions. Finally, the obtained solid was dried overnight at $60^{\circ} \mathrm{C}$ and finally, calcined $2 \mathrm{~h}$ at $300^{\circ} \mathrm{C}$.

\subsection{Catalysts characterization}

BET specific surface areas were measured by nitrogen adsorption at liquid nitrogen temperature in a Micromeritics ASAP 2000 apparatus. Before analysis, the samples were degassed $2 \mathrm{~h}$ at $150^{\circ} \mathrm{C}$ in vacuum.

The cerium and copper contents of the samples were determined by X-ray fluorescence spectrometry (XRF) in a Panalytical AXIOS PW4400 sequential spectrophotometer with a rhodium tube as the source of radiation.

X-ray diffraction (XRD) analysis was performed on a Siemens D 500 diffractometer. Diffraction patterns were recorded with $\mathrm{Cu}$ Ka radiation (40 mA, $40 \mathrm{kV}$ ) over a $10-80^{\circ} 2 \theta$ range using a position-sensitive detector with a step size of $0.01^{\circ}$ and a step time of $7 \mathrm{~s}$.

The Raman spectra were recorded in a dispersive Horiva Jobin Yvon LabRam HR800 microscope, with a $20 \mathrm{mWHe-Ne}$ green laser $(532,14 \mathrm{~nm})$, without filter, and with a $600 \mathrm{~g} \cdot \mathrm{mm}^{-1}$ grating. The microscope used a $50 \mathrm{x}$ objective and a confocal pinhole of $100 \mu \mathrm{m}$. The Raman spectrometer is calibrated using a silicon wafer.

The reducibility studies were carried out on a pilot plant built by PID Eng\&Tech in TPR mode equipped with a $\mathrm{VINCl}$ thermal conductivity detector. The experiments were done by a thermo-programmed reduction (TPR) of $50 \mathrm{mg}$ of catalyst, in a $\mathrm{H}_{2}$ flow of $5 \%$ diluted in $\mathrm{Ar}$ (total flow $=50 \mathrm{~mL} / \mathrm{min}$ ), using a temperature ramp of $10{ }^{\circ} \mathrm{C} / \mathrm{min}$ from room temperature to $900{ }^{\circ} \mathrm{C}$.

The Zeta Potential was measured by using a MALVERN Zetasizer 2000 instrument. The solids were dispersed in an aqueous solution of $0.003 \mathrm{M} \mathrm{NaCl}$. The $\mathrm{pHs}$ of the solutions were adjusted with $\mathrm{HNO}_{3}$ or $\mathrm{NaOH}$ solutions.

Rheological properties of the slurries were measured in a rotational viscosimeter HAAKE, model VT 500, geometry NV.

The adherence of the catalytic layer deposited onto the substrates was 
evaluated using an ultrasonic technique. The weight loss caused by the exposure of the sample to ultrasound is measured. The structured supports immersed in petroleum ether were submitted to an ultrasonic treatment for 30 min at room temperature. After that, the samples were dried and calcined. The weight loss was determined by the difference in the mass of the samples before and after the ultrasonic test. The results are presented in terms of the retained amount of coating on the monolith, expressed as percentage.

\subsection{Catalytic activity measurements}

The CO-PROX reaction was carried out at atmospheric pressure in a PID Eng\&Tech Microactivity set-up, employing a stainless steel tubular reactor with internal diameter of $9 \mathrm{~mm}$ and a constant feed stream flow rate of $100 \mathrm{~cm}^{3} \cdot \mathrm{min}^{-1}$ (STP). The catalyst (100 $\mathrm{mg}$, particle size in the 100-200 mm range) was diluted with crushed glass particles in the same particle size range forming a bed of about $5 \mathrm{~mm}$ in length. The experimental runs were carried out in a flow containing 50 vol. \% $\mathrm{H}_{2}, 2$ vol. \% CO and 1 vol. \% $\mathrm{O}_{2}$ concentrations using $\mathrm{N}_{2}$ as balance. The reaction temperature was increased from $50-60$ to $190-250{ }^{\circ} \mathrm{C}$ in steps of $10^{\circ} \mathrm{C}$. For each step the temperature was stabilized and data were recorded at steady-state conditions. Fresh catalyst was loaded into the reactor after each complete run. Some experiments carried out at the same space-time but at varying gas linear velocities confirmed the absence of external mass transfer effects. On-line analyses of the feed and products streams were performed on an Agilent 7890 gas chromatograph equipped with a Porapak $\mathrm{Q}$, two Molecular Sieve 5A and two Hayesep Q columns and two TCD detectors and a FID detector.

The same computerized PID Eng\&Tech Microactivity set-up was used to study the reaction in the microchannel reactor, replacing the tubular stainless steel reactor for the built microchannel reactor the same compositions were chosen but $300 \mathrm{~cm}^{3} \cdot \mathrm{min}^{-1}$ (STP) feed stream flow rate since $300 \mathrm{mg}$ catalyst was loaded in the microchannel block. To study the effect of $\mathrm{CO}_{2}$ and $\mathrm{H}_{2} \mathrm{O}$, a series of experiments keeping constant the $\mathrm{H}_{2}$ content of the feed stream set at 50 vol. \%, and both the $\mathrm{CO}$ and $\mathrm{O}_{2}$ concentrations fixed at 1 vol.\% were carried out. The $\mathrm{CO}_{2}$ and $\mathrm{H}_{2} \mathrm{O}$ concentrations in the feed were varied within the 2-10 vol.\% 
and $0-20$ vol.\% ranges, respectively, using $\mathrm{N}_{2}$ as balance. The microactivity reference hot box controlled the reaction temperature. For each step the temperature was stabilized and data were recorded at steady-state conditions.

\section{Microchannel reactor}

The metallic microchannel reactor was manufactured using Al-alloyed ferritic stainless steel (for instance, Fecralloy $\AA$ ), since ferritic alloys containing $3-5 \%$ of aluminium produce by thermal treatment an $\mathrm{Al}_{2} \mathrm{O}_{3}$ layer that favours the interaction with the catalytic coating [19-22]. The Fecralloy consisted of $\mathrm{Cr} 22 \%$, Al $4.8 \%$, Si 0.3\%, Y 0.3\%, and Fe balance [21].

Characterization of the joined steel plates were carried out by optical and electron microscopy. Specimens were extracted from the samples, grinded with

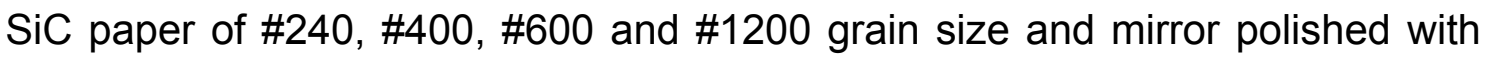
0,3 and $0,1 \mu \mathrm{m} \mathrm{Al}_{2} \mathrm{O}_{3}$ powder. Etching with Vilella's reagent developed the microstructure. Sample observation in the as polished an etched conditions was done in a Leica-DM-IRM optical microscope equipped with a digital camera (Leica DC300). In order to identify metallic and non-metallic inclusions as well as to determine local compositions, the as-polished samples were also observed by SEM using a JEOL 5400 system equipped with secondary and backscattered electron and $\mathrm{x}$-ray detectors.

Microchannels were fabricated by micro-milling $1 \mathrm{~mm}$ thick ferritic stainless steel plates. Each plate has 10 square channels of $750 \mu \mathrm{m}$ separated between them $300 \mu \mathrm{m}$ machined in a $20 \times 20 \mathrm{~mm}^{2}$ plate. This process results in channels with $56 \mathrm{~mm}^{2}$ geometric surface and $700 \mu \mathrm{m}$ hydraulic radius.

In order to minimize the high pressures and processing times required for solid state bonding the ferritic stainless steel plates were joined together using the transient liquid phase (TLP) bonding process. The TLP bonding process uses interlayers, which either contain melting point depressants (e.g. B, Si or P) or form an eutectic with the parent metal being bonded. The joint is held at the bonding temperature until the melting point depressants are lost from the liquid interlayer by diffusion and the liquid interlayer solidifies isothermally due to the change in composition of the bond. This technique has been previously used to 
join different alloy systems including duplex stainless steels [23-29]. Figure 1 is a schematic picture of the steel plates-metallic glass assembly used in this work.

For TLP bonding, a nickel-based interlayer with a composition of Ni-14B-7Si (wt $\%$, Goodfellow) was used. This interlayer was an amorphous melt spun foil with a thickness of $25 \mu \mathrm{m}$. The bonding process was performed in vacuum using a test machine developed by Microtest that allows the control of the applied force, temperature and time allowing rapid heating up to the bonding temperature. Various trials were conducted to establish the optimum bonding parameters, varying the temperature, applied force and time. A bonding temperature of $850^{\circ} \mathrm{C}$ with an applied force of 2,8 $\mathrm{kN}(\sim 7 \mathrm{MPa})$ was selected. Low temperature and light pressure applied is required for keeping the mechanical integrity of the machined plate since the low creep strength of the selected alloy [30]. Figure 2 shows the macroscopic aspects of joined plates at different applied forces clearly shown that for applied pressures above $15 \mathrm{MPa}(6,0 \mathrm{kN})$ and $900^{\circ} \mathrm{C}$ creep results in a strong deformation of the machined microchannels. The TLP bonded samples were finally treated at $1200^{\circ} \mathrm{C}$ for $5 \mathrm{~h}$.

After the joining procedure the two ferritic steel plates are separated by a metallic alloy ca. $25 \mu \mathrm{m}$ thick whose composition mainly corresponds to that of the Ni-based interlayer. The microstructure of the joined area is characterized by the existence of two ferritic layers in which the precipitation of chromium carbides is evident separated by the Ni-based interlayer. A strong chromium carbide precipitation occurs at the stainless steel-interlayer interfaces, figure $3 \mathrm{~A}$. Upon post-processing at $1200^{\circ} \mathrm{C}$ a single phase recrystallizes. EDX analysis across the joined area show that the $\mathrm{Fe}, \mathrm{Cr}, \mathrm{Al}$ and $\mathrm{Al}$ line profiles are almost flat indicating interdiffusion of the Ni-based interlayer and the ferritic steel, except for some chromium maximum and iron minimum corresponding to the presence of chromium carbide precipitates. Using nickel as a marker, it should be noted that this element is absent in the ferritic steel this diffusion is clearly seen. Figure 3D shows the Gaussian-fitted Ni line profile across the joined area, the FWHM of the Gaussian distribution, ca. $400 \mu \mathrm{m}$, is considerable higher than the thickness of the used interlayer demonstrating the formation of a single phase upon the designed joining procedure. 
Micromachining and joining of the steel plates resulted in a microblock that was housed in Al-alloyed ferritic steels cases designed using CFD algorithms for ensuring homogeneous flow through all the channels, the housing was join together using graphite seals, figure 4. Finally, the microchannel block was fitted with thermocouples monitoring inlet and outlet temperatures as well as temperature gradients within the microblock. Manifolding and instrumentation of the microreactor was implemented in a computerized Microactivity Reference Catalytic Reactor from PID Eng\&Tech that controls the reaction temperature in the reactor through the temperature control of the hot box.

Prior to the assembly of the microreactor the microchannel block was coated with the catalyst. For improving the interaction between the washcoated layer and the metallic support, the surface of the microchannel block was modified generating an oxide scale that enhances adhesion of the catalytic layer both mechanically, through the generated roughness, and chemically through the interaction between this oxide scale and the catalytic material.

Modified surfaces are obtained upon heating in air at elevated temperatures being the resulting oxide scale an excellent substrate to adhere catalysts [1922]. The optimal treatment parameters remain usually undisclosed. Upon heating at $900{ }^{\circ} \mathrm{C}$ for $22 \mathrm{~h}$ in air the microchannel block a homogeneous surface layer of $\alpha-\mathrm{Al}_{2} \mathrm{O}_{3}$ is formed as confirmed by DRX. SEM micrographs, figure 5 , clearly show the needle-like structure of the formed whiskers having thicknesses ranging between 3 and $6 \mu \mathrm{m}$.

Washcoating was selected for coating the microchannels with the $\mathrm{CuO} / / \mathrm{CeO}_{2}$ catalyst. The first step for washcoating a metallic substrate is to prepare stable slurries of the catalyst to be deposited. Particle size, solid content of the suspension and $\mathrm{pH}$ of the catalyst slurry are parameters that influence the slurry stability. The particle size of our catalyst, $d_{90}=0.5 \mu \mathrm{m}$, is well below $10 \mu \mathrm{m}$ the upper recommend limit for preparing stable slurries [31] therefore the usual ball milling process for reducing particle size was avoided. The isoelectric point (IEP) of the catalyst is ca. 7 and therefore the $\mathrm{pH}$ was fixed at 4 for ensuring high values of zeta potential and then high repulsions between the particles, favouring the stability of the slurries [32]. The use of additives for the slurry formulation attempts to improve the catalyst adherence and the washcoating 
drying process. The addition of colloidal alumina, that presents a narrow particle size distribution, improves the catalyst adherence [31,33] according to the model previously proposed by Nijhuis et al. [34] a bimodal particle size distribution increase adherence since the smaller particles are located between the bigger ones. The use of polyvinyl alcohol (PVOH) helps in preventing crack formation during the drying process improving the wetting properties of the catalytic layer. After several trials of slurry formulation for washcoating the following proportions of catalyst and additives was selected: $76 \%$ catalyst content, $7 \% \mathrm{PVOH}(\mathrm{w} / \mathrm{w}), 17 \%$ colloidal alumina $(\mathrm{w} / \mathrm{w})$ and $\mathrm{pH}$ of the suspension adjusted to 4 with diluted $\mathrm{HNO}_{3}$.

Assuming the Einstein model for the diluents dispersion of hard spheres, the viscosity of ideal water slurries only depends on the solid content, being higher as the solid content increases [35]. In the case of the $\mathrm{CuO}_{x} / \mathrm{CeO}_{2}$ catalyst the viscosity ranges from $20 \mathrm{cps}$ for $15 \%$ solid content to $200 \mathrm{cps}$ for a dispersion containing $25 \%$ solids. The viscosity of the catalytic slurry is the key parameter in controlling the coating process; a detailed description of the different factors influencing the washcoating process is given elsewhere [31, 33]. Slurry with $18 \%$ solid concentration provides an excellent compromise between the slurry wetting properties and catalyst loading. Figure 6 presents the amount of loaded catalyst over the substrates as a function of the number of coatings. The specific load increases almost linearly with the number of coatings. The washcoating method gives additive and homogenous results. Low viscosities allow to obtain highly adherent and homogeneous coatings but with low specific loads. Thus for obtaining the target loading numerous coating are required. On the contrary, high viscosity will allow high specific load per coating although with lower homogeneities (i.e. accumulations, channel blocking) resulting in less adherent coatings [33]. The slurry prepared in these conditions was stable for 96 hours. Once the microchannels were immersed in the slurry the elimination of the excess was done by air blowing for microchannels $\left(2 \mathrm{~L} \cdot \mathrm{min}^{-1}\right)$. Finally, the microchannel block was dried at $120^{\circ} \mathrm{C}$ for 30 minutes between coatings and after the last coating procedure the microchannel block was calcined at $300^{\circ} \mathrm{C}$ for 3 hours $\left(1^{\circ} \mathrm{C} / \mathrm{min}\right)$. This procedure resulted in a microchannel block loading of $5,46 \mathrm{mg} \cdot \mathrm{cm}^{-2}$ catalyst after eight washcoating processes. The adherence of 
the resulting catalytic layer is better than $99,95 \%$.

\section{Results and discussion}

\subsection{Powder Catalyst.}

The XRD pattern of the $\mathrm{CuO}_{x}-\mathrm{CeO}_{2}$ catalyst corresponds to that of the $c-\mathrm{CeO}_{2}$ fluorite structure (figure 7). The observed reflections can be indexed to (111), (200), (220) and (311) crystallographic planes of the cubic ceria phase. The diffraction lines corresponding to copper containing phases are undetectable. The lattice parameter calculated from these reflections $(a=5,4131)$ closely agrees with the one reported in the literature [36, 37] accounting for the presence of oxygen vacancies and therefore for the presence of trivalent cerium ions. However, for the sake of simplicity this non-stoichiometric phase will be referred as $\mathrm{CeO}_{2}$ all over the text. Similar results have been previously reported by Liu and co-workers for $\mathrm{CuO}-\mathrm{CeO}_{2}$ synthesized by a chelating method [38] proposing the dispersion of $\mathrm{CuO}$ on the ceria surface without formation of solid solution. The Raman spectrum of the catalyst (figure 8) presents only a strong band centred at $463 \mathrm{~cm}^{-1}$ characteristic of the $\mathrm{CeO}_{2}$ cubic structure accompanied by a broad band at $612 \mathrm{~cm}^{-1}$ associated to the presence of surface oxygen vacancies. This band increases considerably upon heating as a result of the dehydroxylation of the surface. A similar behaviour has been previously reported for europium-doped ceria [39]. Features that might be ascribed to copper phases or ceria-copper interactions are not observed.

The textural properties of the catalysts are summarized in table 1.

The TPR profile (figure 9) of the $\mathrm{CuO}_{x}-\mathrm{CeO}_{2}$ catalyst shows three reduction peaks distributed in two main reduction zones ( $\mathrm{A}$ and $\mathrm{B})$. The zone at the highest temperatures, zone $\mathrm{B}$, corresponds to the peaks at $727^{\circ} \mathrm{C}$ and $854^{\circ} \mathrm{C}$. This reduction peaks can be associated to the reduction of bulk $\mathrm{Ce}^{4+}[40]$, while the low temperature peak $\left(184^{\circ} \mathrm{C}-\right.$ zone $\left.\mathrm{A}\right)$ is ascribed to the reduction of $\mathrm{Cu}^{2+}$. Table 2 presents the hydrogen consumption for the two zones. Integration of the low temperature peak results in hydrogen consumption ca. $20 \%$ higher than required for completely reduce copper oxides to metallic copper, therefore surface reduction of cerium cations occurs also at this low temperatures through the interaction of copper species with the ceria surface. 
The enhancement of the Ce reducibility by doping ceria with different cations has been widely reported [37, 38, 41, 42]. These doping agents generate a decreasing of the energy barrier for the oxygen migration of the $\mathrm{CeO}_{2}$ network $[43,44]$ and the environment through mechanisms as the oxygen vacancies formation. This process takes place especially at the surface of the material, where this becomes stable through the decreasing of its Gibbs free energy [44]. In this sense, it is possible that the reduction of some surface Ce species takes place at low temperatures, which is in agreement with our results and is pointing out the interaction $\mathrm{Ce}-\mathrm{Cu}$ in the $\mathrm{CeO}_{2}-\mathrm{CuOx}$ system. Mariño et al. [45] also observed a $\mathrm{Cu}-\mathrm{Ce}$ synergy on the surface reduction of ceria using both $\mathrm{CuCe}$ mixed oxides and mechanical mixtures of copper and cerium oxides. In both cases a reduction peak accounting for an overall $\mathrm{H}_{2}$ consumption higher than the stoichiometric amount required to reduce all the copper of the catalyst from $\mathrm{Cu}^{2+}$ to $\mathrm{Cu}^{0}$, evidences, for these authors, that some degree of surface reduction of ceria takes place at low temperatures as a result of copper-cerium interaction in these catalysts. This copper-cerium interaction would result from $\mathrm{H}_{2}$ dissociation on $\mathrm{Cu}^{0}$ particles and further spillover over the ceria surface favouring the low temperature reduction of surface $\mathrm{Ce}^{4+}$ species. Spillover of hydrogen species from reduced copper sites to $\mathrm{ZnO} / \mathrm{SiO}_{2}$ support has been previously claimed as responsible for the formation of formate species during carbon oxides hydrogenation over $\mathrm{Cu} / \mathrm{ZnO} / \mathrm{SiO}_{2}$ methanol-synthesis catalysts [46].

Therefore, the TPR data account for the reduction of copper together with partial surface reduction of ceria at low temperature followed by bulk ceria reduction at high temperatures. This in contrast with the sequential process reported by Liu et al. [38] that established a reduction process for $\mathrm{CuO}-\mathrm{CeO}_{2}$ in four steps: (a) reduction of $\mathrm{CuO}$ with small particle sizes; (b) reduction of $\mathrm{CuO}$ with large particle sizes; (c) reduction of $\mathrm{Cu}_{2} \mathrm{O}$; (d) reduction of surface or bulk oxygen species of ceria.

\subsection{Catalytic activity of the powder and the microchannel reactor}

The catalytic activity of the $\mathrm{CuO}_{x}-\mathrm{CeO}_{2}$ catalyst was studied in a micro packedbed reactor. The conversion of $\mathrm{CO}$ and the $\mathrm{O}_{2}$ selectivity to $\mathrm{CO}_{2}$ for the $\mathrm{CO}$ - 
PROX reaction in the absence of $\mathrm{CO}_{2}$ or $\mathrm{H}_{2} \mathrm{O}$ in the feed is shown in figure 10 . The CO conversion increases with temperature reaching a maximum at ca. $150^{\circ} \mathrm{C}$ while the selectivity continuously decreases. This behaviour is in accordance with previous reports in the literature $[47,48]$. In both cases the selectivity decreases with the reaction temperature, which is result of the higher activation energy for $\mathrm{H}_{2}$ oxidation than for $\mathrm{CO}$ oxidation. A detailed description of the CO-PROX process for this catalyst taking into account the oxidation of $\mathrm{CO}$ and $\mathrm{H}_{2}$ simultaneously and the reverse WGS is given elsewhere [49]. The activation energy measured for the oxidation of CO $36,9 \mathrm{~kJ} \cdot \mathrm{mol}^{-1}$ is very close to the value measured by Jernigan and Somorjai over metallic copper (37.6 $\mathrm{kJ} \cdot \mathrm{mol}^{-1}$ ) [50], which is in accordance with the presence of metallic copper at the reaction conditions as deduced from the TPR experiments. On the other hand, the ratio between the area of the vibrational mode for oxygen vacancies and for the $F_{2 g}$ vibrational mode of the ceria phase under the actual reaction conditions is higher than the same ratio for the activated catalyst. This result points to the increase in the number of oxygen vacancies at the reaction steady state and therefore to the importance of the $\mathrm{Ce}^{4+} / \mathrm{Ce}^{3+}$ redox couple in the activity towards the oxidation of $\mathrm{CO}$ under CO-PROX conditions. OperandoDRIFTS experiments carried out by Gamarra et al. [51] demonstrate that the $\mathrm{CO}$ oxidation activity under CO-PROX conditions of the $\mathrm{CuO}-\mathrm{CeO}_{2}$ catalysts is correlated to the degree of reduction achieved under reaction conditions in the surface dispersed copper oxide entities.

The washcoating procedure requires the use of additives, colloidal alumina and $\mathrm{PVOH}$, as well as to acidify the resulting suspension in order to increase the slurry stability. Therefore, textural properties of the coating would be affected by the presence of the alumina additive and the copper amount by possible leaching of the active phase at acid $\mathrm{pH}$.

The textural properties of the coated solid are altered since the presence of the colloidal alumina resulting in higher surface area and wider average pore diameter. Similarly, the low $\mathrm{pH}$ required for stabilizing the slurry may modify the catalyst due to leaching of the active phase. In order to model the behaviour of the catalyst at the low $\mathrm{pH}$ required for preparing the slurry the catalyst was submitted to an acid solution prepared using $\mathrm{HNO}_{3}$ at $\mathrm{pH}=2$ for 15 hours without 
stirring. After drying and calcining the catalyst, the measured amount of copper is reduced by ca. $40 \%$ (copper content measured by $\mathrm{FRX}$ is $6 \%$ ) and the surface increased from 75.9 to $113 \mathrm{~m}^{2} \cdot \mathrm{g}^{-1}$.

The catalytic activity and the $\mathrm{O}_{2}$ selectivity to $\mathrm{CO}_{2}$ of the leached solid is also modified, figure 9 . The catalyst, after copper leaching, presents a lower activity for $\mathrm{CO}$ oxidation but higher selectivity to $\mathrm{CO}_{2}$ in the whole temperature range.

The lower copper loading together with the higher surface area results in a modification of the copper oxide dispersion. Bion et al. [10] report a collection of studies for the CO-PROX reaction over copper-ceria catalysts showing that not only the $\mathrm{CO}$ oxidation proceeds more readily as copper content of the catalyst increases but also the activity of the samples for the undesirable $\mathrm{H}_{2}$ oxidation increases with copper content. A limit of $6 \% \mathrm{w} / \mathrm{w}$ of copper is estimated as the limit in which the copper phase is completely dispersed on the ceria surface for ceria supports with surface areas in the range of $100 \mathrm{~m}^{2} \cdot \mathrm{g}^{-1}$, above this value the formation of copper oxide islands occurs shifting the $\mathrm{CO}$ conversion curves vs. temperature to lower temperatures as copper loading increases as observed in figure 10.

The catalytic activity shown by the copper-ceria catalyst in the microchannel reactor is presented in figure 11. The $\mathrm{CO}$ conversion in the absence of $\mathrm{CO}_{2}$ or $\mathrm{H}_{2} \mathrm{O}$ in the feed using the stoichiometric amount of oxygen is similar to that found in the powder catalyst; however the selectivity is slightly higher probably due to the heat transfer characteristics of the microchannel block that avoids the formation of hot spots.

Considerably amounts of $\mathrm{CO}_{2}$ and $\mathrm{H}_{2} \mathrm{O}$ present in the reformate gas stream are a critical issue for CO-PROX reactions. Figure 12 presents $\mathrm{CO}$ conversions at $150^{\circ} \mathrm{C}$ as a function of $\mathrm{CO}_{2}$ and $\mathrm{H}_{2} \mathrm{O}$ concentrations in the reaction mixture. The presence of $\mathrm{CO}_{2}$ affects negatively the $\mathrm{CO}$ conversion mainly due to its elevated heat of adsorption [49]. On the contrary, the $\mathrm{O}_{2}$ selectivity to $\mathrm{CO}_{2}$ is hardly affected $(88 \pm 5 \%)$ pointing to an equivalent effect on both $\mathrm{CO}$ and $\mathrm{H}_{2}$ oxidation reactions as previously reported $[47,52]$. The $C O$ conversion and the $\mathrm{O}_{2}$ selectivity to $\mathrm{CO}_{2}$, however, remains almost unaltered by the presence of $\mathrm{H}_{2} \mathrm{O}$ in the feed stream showing the same excellent tolerance to water previously reported by Liu and Flytzani-Stephanopoulos for $\mathrm{Cu}-\mathrm{Ce}, \mathrm{Co}-\mathrm{Ce}$ and 
Cu-Zr fluorite oxide composite catalysts [53].

\section{Conclusions}

The viability of the TLP technique using amorphous melt spuns as interlayer for bonding micromilled stainless steel plates is demonstrated. A recrystallization treatment is required for recovering the heat-affected zone and obtaining a homogeneous microstructure. Slurry formulation for coating the resulting microchannel block results in partial leaching of the copper active phase. This leaching procedure, however, enhances the $\mathrm{O}_{2}$ selectivity to $\mathrm{CO}_{2}$ by increasing the active phase dispersion as a consequence of the increase in surface area and the reduction of copper loading. A 20-30 $\mu \mathrm{m}$ thick catalytic layer is obtained after coating the microchannel block with the formulated slurry showing adherences better than $99 \%$.

The catalytic activity of both the powder packed bed reactor and the coated microchannel reactor is similar but the $\mathrm{O}_{2}$ selectivity to $\mathrm{CO}_{2}$ obtained in the microchannel reactor is higher.

\section{Acknowledgements}

Financial support by PETROBRAS and the Spanish Ministry of Science and Innovation through (MAT-2006-12386-C05) and (ENE-2009-14522-C05-01). O.H. Laguna and F.J. Echave thank to the same Ministry for their FPI fellowships (BES-2007-14409) and (BES-2007-15297) respectively. Junta de Andalucía (P06-TEP-08480) is gratefully acknowledged, also by S.A. Cruz for her fellowship. This work has been co-financed by FEDER funds from European Union. TEKNIKER is acknowledged for the mechanical construction.

\section{References}

[1] J.D. Holladay, J. Hu, D.L. King, Y. Wang, An overview of hydrogen production technologies, Catalysis Today, 139 (2009) 244-260.

[2] A. Gavriilidis, P. Angeli, E. Cao, K.K. Yeong, Y.S.S. Wan, Technology and applications of microengineered reactors, Chemical Engineering Research and Design, 80 (2002) 3-30.

[3] G. Kolb, V. Hessel, Micro-structured reactors for gas phase reactions, Chemical Engineering Journal, 98 (2004) 1-38. 
[4] X. Ouyang, L. Bednarova, R.S. Besser, P. Ho, Preferential oxidation (PrOx) in a thin-film catalytic microreactor: Advantages and limitations, AIChE Journal, 51 (2005) 1758-1772.

[5] X. Ouyang, R.S. Besser, Effect of reactor heat transfer limitations on CO preferential oxidation, Journal of Power Sources, 141 (2005) 39-46.

[6] X. Ouyang, R.S. Besser, CO Clean-up: Preferential Oxidation, in: V. Hessel, A. Renken, J.C. Schouten and J.-I. Yoshida (Eds.), Micro Process Engineering, Vol. 2: Devices, Reactions and Applications, Wiley-VCH Verlag, Weinheim, 2009, p. 479.

[7] G. Kolb, C. Hofmann, M. O'Connell, J. Schürer, Microstructured reactors for diesel steam reforming, water-gas shift and preferential oxidation in the kiloWatt power range, Catalysis Today, 147 (2009) S176-S184.

[8] M. O'Connell, G. Kolb, K.P. Schelhaas, J. Schuerer, D. Tiemann, A. Ziogas, V. Hessel, The development and evaluation of microstructured reactors for the water gas shift and preferential oxidation reactions in the $5 \mathrm{~kW}$ range, International Journal of Hydrogen Energy, 35 (2010) 2317-2327.

[9] G. Kolb, Fuel processing for fuel cells. Wiley-VCH, (2008).

[10] N. Bion, F. Epron, M. Moreno, F. Mariño, D. Duprez, Preferential oxidation of carbon monoxide in the presence of hydrogen (PROX) over noble metals and transition metal oxides: Advantages and drawbacks, Topics in Catalysis, 51 (2008) 76-88.

[11] C.D. Dudfield, R. Chen, P.L. Adcock, Compact CO selective oxidation reactor for solid polymer fuel cell powered vehicle application, Journal of Power Sources, 86 (2000) 214-222.

[12] C.D. Dudfield, R. Chen, P.L. Adcock, A carbon monoxide PROX reactor for PEM fuel cell automotive application, International Journal of Hydrogen Energy, 26 (2001) 763-775.

[13] S. Srinivas, A. Dhingra, H. Im, E. Gulari, A scalable silicon microreactor for preferential CO oxidation: Performance comparison with a tubular packed-bed microreactor, Applied Catalysis A: General, 274 (2004) 285-293.

[14] G. Chen, Q. Yuan, H. Li, S. Li, CO selective oxidation in a microchannel reactor for PEM fuel cell, Chemical Engineering Journal, 101 (2004) 101-106.

[15] K.-Y. Kim, J. Han, S.W. Nam, T.-H. Lim, H.-I. Lee, Preferential oxidation of CO over $\mathrm{CuO} / \mathrm{CeO}_{2}$ and $\mathrm{Pt}-\mathrm{Co} / \mathrm{Al}_{2} \mathrm{O}_{3}$ catalysts in micro-channel reactors, Catalysis Today, 131 (2008) 431-436.

[16] S.M. Hwang, O.J. Kwon, S.H. Ahn, J.J. Kim, Silicon-based micro-reactor for preferential CO oxidation, Chemical Engineering Journal, 146 (2009) 105-111.

[17] K.Y. Kim, S.W. Nam, J. Han, S.P. Yoon, T.H. Lim, H.I. Lee, Development of a multi-layered micro-reactor coated with $\mathrm{Pt}-\mathrm{Co} / \mathrm{Al} 2 \mathrm{O} 3$ catalyst for preferential oxidation of $\mathrm{CO}$, Journal of Industrial and Engineering Chemistry, 14 (2008) 853-859.

[18] P.V. Snytnikov, M.M. Popova, Y. Men, E.V. Rebrov, G. Kolb, V. Hessel, J.C. Schouten, V.A. Sobyanin, Preferential $\mathrm{CO}$ oxidation over a copper-cerium oxide catalyst in a microchannel reactor, Applied Catalysis A: General, 350 (2008) 53-62.

[19] P. Avila, M. Montes, E.E. Miró, Monolithic reactors for environmental applications: A review on preparation technologies, Chemical Engineering Journal, 109 (2005) 11-36.

[20] A. Cybulski, J.A. Moulijn, Monoliths in heterogeneous catalysis, Catalysis Reviews - Science and Engineering, 36 (1994) 179-270.

[21] D.M. Frías, S. Nousir, I. Barrio, M. Montes, L.M. Martínez T, M.A. Centeno, J.A. Odriozola, Nucleation and growth of manganese oxides on metallic surfaces as a tool to prepare metallic monoliths, Applied Catalysis A: General, 325 (2007) 205-212.

[22] L.M. Martínez T, M.I. Domínguez, N. Sanabria, W.Y. Hernández, S. Moreno, R. Molina, J.A. Odriozola, M.A. Centeno, Deposition of Al-Fe pillared bentonites and gold supported Al-Fe pillared bentonites on metallic monoliths for catalytic oxidation reactions, Applied Catalysis A: General, 364 (2009) 166-173. 
[23] T.I. Khan, E.R. Wallach, Transient liquid phase diffusion bonding and associated recrystallization phenomenon when joining ODS ferritic superalloys, Journal of Materials Science, 31 (1996) 2937-2943.

[24] J.R. Askew, J.F. Wilde, T.I. Khan, Transient liquid phase bonding of 2124 aluminium metal matrix composite, Materials Science and Technology, 14 (1998) 920-924.

[25] A. Ekrami, T.I. Khan, Transient liquid phase diffusion bonding of oxide dispersion strengthened nickel alloy MA758, Materials Science and Technology, 15 (1999) 946-950.

[26] Y. Guan, W.F. Gale, Transient liquid phase bonding of a $\mathrm{Hf}$ bearing single crystal nickel aluminide to MM247 superalloy, Materials Science and Technology, 15 (1999) 207-212.

[27] T.I. Khan, N. Orhan, M. Eroglu, Transient liquid phase bonding of a microduplex stainless steel using amorphous interlayers, Materials Science and Technology, 18 (2002) 396-400.

[28] T.I. Khan, M.J. Kabir, R. Bulpett, Effect of transient liquid-phase bonding variables on the properties of a micro-duplex stainless steel, Materials Science and Engineering A, 372 (2004) 290-295.

[29] R.K. Saha, S. Wei, T.I. Khan, A comparison of microstructural developments in TLP diffusion bonds made using ODS Ni alloy, Materials Science and Engineering A, 406 (2005) 319327.

[30] S.R.J. Saunders, H.E. Evans, M. Li, D.D. Gohil, S. Osgerby, Oxidation growth stresses in an alumina-forming ferritic steel measured by creep deflection, Oxidation of Metals, 48 (1997) 189-200.

[31] L.C. Almeida, F.J. Echave, M.A. Sanz, M.A. Centeno, G. Arzamendi, L.M. Gandía, E.F. SouzaAguiar, J.A. Odriozola, M. Montes, Fischer-Tropsch Synthesis in Microchannels, 11th International Conference on Microreaction Technology, $11^{\text {th }}$ International Conference on Microreaction Technology, March 8-10, 2010, Kyoto Research Park, Kyoto, Japan. Submitted to Chemical Engineering Journal.

[32] S. Vallar, D. Houivet, J. El Fallah, D. Kervadec, J.M. Haussonne, Oxide slurries stability and powders dispersion: Optimization with zeta potential and rheological measurements, Journal of the European Ceramic Society, 19 (1999) 1017-1021.

[33] L.C. Almeida, F.J. Echave, S. O, M.A. Centeno, J.A. Odriozola, M. Montes, Washcoating of metallic monoliths and microchannel reactors, Studies in Surface Science and Catalysis, Accepted, (2010).

[34] T.A. Nijhuis, A.E.W. Beers, T. Vergunst, I. Hoek, F. Kapteijn, J.A. Moulijn, Preparation of monolithic catalysts, Catalysis Reviews - Science and Engineering, 43 (2001) 345-380.

[35] T.C. Patton, Paint Flow and Pigment Dispersion, $2^{\text {nd }}$ ed. John Wiley \& Sons, New York, (1979).

[36] W.Y. Hernández, M.A. Centeno, F. Romero-Sarria, J.A. Odriozola, Synthesis and characterization of $\mathrm{Ce}_{1-x} \mathrm{Eu}_{\mathrm{x}} \mathrm{O}$ 2-x/2 mixed orxides and their catalytic activities for $\mathrm{CO}$ oxidation, Journal of Physical Chemistry C, 113 (2009) 5629-5635.

[37] O.H. Laguna, M.A. Centeno, G. Arzamendi, L.M. Gandía, F. Romero-Sarria, J.A. Odriozola, Iron-modified ceria and Au/ceria catalysts for Total and Preferential Oxidation of CO (TOX and PROX), Catalysis Today, In Press, Corrected Proof.

[38] Z. Liu, R. Zhou, X. Zheng, Comparative study of different methods of preparing $\mathrm{CuO}-\mathrm{CeO}_{2}$ catalysts for preferential oxidation of $\mathrm{CO}$ in excess hydrogen, Journal of Molecular Catalysis A: Chemical, 267 (2007) 137-142.

[39] W.Y. Hernández, M.A. Centeno, F. Romero-Sarria, J.A. Odriozola, Synthesis and characterization of $\mathrm{Ce}_{1-\mathrm{x}} \mathrm{Eu}_{\mathrm{x}} \mathrm{O}_{2-\mathrm{x} / 2}$ mixed oxides and their catalytic activities for $\mathrm{CO}$ oxidation, Journal of Physical Chemistry C, 113 (2009) 5629-5635.

[40] S. Damyanova, B. Pawelec, K. Arishtirova, M.V.M. Huerta, J.L.G. Fierro, Study of the surface and redox properties of ceria-zirconia oxides, Applied Catalysis A: General, 337 (2008) 86-96.

[41] T. Masui, Y. Peng, K.-i. Machida, G.-y. Adachi, Reduction Behavior of $\mathrm{CeO}_{2}-\mathrm{ZrO}_{2}$ Solid Solution Prepared from Cerium Zirconyl Oxalate, Chemistry of Materials, 10 (1998) 4005-4009. 
[42] G. Avgouropoulos, M. Manzoli, F. Boccuzzi, T. Tabakova, J. Papavasiliou, T. Ioannides, V. Idakiev, Catalytic performance and characterization of Au/doped-ceria catalysts for the preferential CO oxidation reaction, Journal of Catalysis, 256 (2008) 237-247.

[43] H. Bao, X. Chen, J. Fang, Z. Jiang, W. Huang, Structure-activity Relation of $\mathrm{Fe}_{2} \mathrm{O}_{3}-\mathrm{CeO}_{2}$ Composite Catalysts in CO Oxidation, Catalysis Letters, 125 (2008) 160-167.

[44] P.J. Gellings, H.J.M. Bouwmeester, Ion and mixed conducting oxides as catalysts, Catalysis Today, 12 (1992) 1-101.

[45] F. Mariño, G. Baronetti, M. Laborde, N. Bion, A. Le Valant, F. Epron, D. Duprez, Optimized $\mathrm{CuO}-\mathrm{CeO} 2$ catalysts for COPROX reaction, International Journal of Hydrogen Energy, 33 (2008) 1345-1353.

[46] G.J. Millar, C.H. Rochester, S. Bailey, K.C. Waugh, A combined temperature-programmed reaction spectroscopy and Fourier-transform infrared spectroscopy study of $\mathrm{CO} 2-\mathrm{H} 2$ and $\mathrm{CO}-$ $\mathrm{CO} 2-\mathrm{H} 2$ interactions with model $\mathrm{ZnO} / \mathrm{SiO} 2, \mathrm{Cu} / \mathrm{SiO} 2$ and $\mathrm{Cu} / \mathrm{ZnO} / \mathrm{SiO} 2$ methanol-synthesis catalysts, Journal of the Chemical Society, Faraday Transactions, 88 (1992) 2085-2093.

[47] G. Avgouropoulos, T. Ioannides, H.K. Matralis, J. Batista, S. Hocevar, $\mathrm{CuO}-\mathrm{CeO}_{2}$ mixed oxide catalysts for the selective oxidation of carbon monoxide in excess hydrogen, Catalysis Letters, 73 (2001) 33-40.

[48] G. Avgouropoulos, T. Ioannides, C. Papadopoulou, J. Batista, S. Hocevar, H.K. Matralis, A comparative study of $\mathrm{Pt} / \gamma-\mathrm{Al}_{2} \mathrm{O}_{3}, \mathrm{Au} / \alpha-\mathrm{Fe}_{2} \mathrm{O}_{3}$ and $\mathrm{CuO}-\mathrm{CeO}_{2}$ catalysts for the selective oxidation of carbon monoxide in excess hydrogen, Catalysis Today, 75 (2002) 157-167.

[49] G. Arzamendi, I. Uriz, P.M. Diéguez, O.H. Laguna, W.Y. Hernández, A. Álvarez, M.A. Centeno, J.A. Odriozola, M. Montes, L.M. Gandía, Selective CO removal over Au/CeFe and $\mathrm{CeCu}$ catalysts in microreactors studied through kinetic analysis and CFD simulations, $11^{\text {th }}$ International Conference on Microreaction Technology, March 8-10, 2010, Kyoto Research Park, Kyoto, Japan. Submitted to Chemical Engineering Journal.

[50] G.G. Jernigan, G.A. Somorjai, Carbon Monoxide Oxidation over Three Different Oxidation States of Copper: Metallic Copper, Copper (I) Oxide, and Copper (II) Oxide - A Surface Science and Kinetic Study, Journal of Catalysis, 147 (1994) 567-577.

[51] D. Gamarra, G. Munuera, A.B. Hungría, M. Fernández-García, J.C. Conesa, P.A. Midgley, X.Q. Wang, J.C. Hanson, J.A. Rodríguez, A. Martínez-Arias, Structure-activity relationship in nanostructured copper-ceria-based preferential CO oxidation catalysts, Journal of Physical Chemistry C, 111 (2007) 11026-11038.

[52] T. Caputo, L. Lisi, R. Pirone, G. Russo, Kinetics of the preferential oxidation of CO over $\mathrm{CuO} / \mathrm{CeO}_{2}$ catalysts in $\mathrm{H}_{2}$-rich gases, Industrial and Engineering Chemistry Research, 46 (2007) 6793-6800.

[53] W. Liu, M. Flytzanistephanopoulos, Total Oxidation of Carbon Monoxide and Methane over Transition Metal Fluorite Oxide Composite Catalysts : I. Catalyst Composition and Activity, Journal of Catalysis, 153 (1995) 304-316. 


\section{TABLE AND FIGURE CAPTIONS}

Table 1. Textural properties of the catalysts

Table 2. Hydrogen consumption during the TPR analysis for the $\mathrm{CuOx}-\mathrm{CeO}_{2}$ solid

Table 3. Parameters chosen for welding the microchannel plates

Figure 1: Schematic picture of the steel plates-metallic glass assembly in crossflow configuration.

Figure 2. Joined Al-alloyed ferritic stainless steel plates at $900^{\circ} \mathrm{C}$ as a function of the applied uniaxial pressure. A) $10 \mathrm{MPa}$ and B) $15 \mathrm{MPa}$

Figure 3. Microstructures of the joined area. A) SEM micrigraph before the recrystallization process; B) Optical micrograph after recrystallizing the microreactor for $5 \mathrm{~h}$ at $1200^{\circ} \mathrm{C}$; C) EDX line profile across the joined are after recrystallization; D) Gaussian fit of the Ni EDX line profile across the joined are after recrystallization. The profile is taken along the line marked in pannel $B$.

Figure 4. Microchannel block and microchannel reactor for the CO-PROX reaction.

Figure 5. SEM micrographs of the $\alpha-\mathrm{Al}_{2} \mathrm{O}_{3}$ formed upon heating at $900{ }^{\circ} \mathrm{C}$ for 22 $\mathrm{h}$ in air the microchannel block

Figure 6. Evolution of the catalyst loading after the drying process as a function of the number of coatings performed. The amount loaded upon calcination is indicated by an arrow and the specific loading is indicated after 4,6 or 8 coatings

Figure 7. XRD pattern of the $\mathrm{CuOx}-\mathrm{CeO}_{2}$ solid

Figure 8. Raman spectra of the $\mathrm{CuOx}-\mathrm{CeO}_{2}$ solid at different temperatures

Figure 9. TPR profile for the prepared $\mathrm{CuO}_{x}-\mathrm{CeO}_{2}$ solid 
Figure 10. $\mathrm{CO}$ conversion (A) and $\mathrm{O}_{2}$ selectivity to $\mathrm{CO}_{2}(\mathrm{~B})$ for the CO-PROX reaction over $\mathrm{CuO}_{x}-\mathrm{CeO}_{2}$ catalysts. Open circles synthesized catalyst; Full circles after leaching in $\mathrm{HNO}_{3}$ at $\mathrm{pH}=2$

Figure 11. $\mathrm{CO}$ conversion $(\mathrm{A})$ and $\mathrm{O}_{2}$ selectivity to $\mathrm{CO}_{2}(\mathrm{~B})$ for the CO-PROX reaction over $\mathrm{CuO}_{x}-\mathrm{CeO}_{2}$ catalysts in a atmosphere with $\mathrm{CO}: \mathrm{O}_{2}: \mathrm{H}_{2}: \mathrm{N}_{2}$ ratios of $2: 1: 50: 47 . F_{\text {(powder) }}=100 \mathrm{Ncm}^{3} \cdot \mathrm{min}^{-1} ; F_{\text {(microchannel) }}=300 \mathrm{Ncm}^{3} \cdot \mathrm{min}^{-1} ; W_{\text {(powder) }}=$ $100 \mathrm{mg} ; \mathrm{W}_{\text {(microchannel) }}=300 \mathrm{mg}$

Figure 12. $\mathrm{CO}$ conversion for the $\mathrm{CO}-\mathrm{PROX}$ reaction over $\mathrm{CuO}_{\mathrm{x}}-\mathrm{CeO}_{2}$ catalysts in the microchannel block as a function of the $\mathrm{CO}_{2}$ and $\mathrm{H}_{2} \mathrm{O}$ concentrations in a atmosphere with $\mathrm{CO}: \mathrm{O}_{2}: \mathrm{H}_{2}: \mathrm{N}_{2}$ ratios of $2: 1: 50$ :balance. $\mathrm{F}=300 \mathrm{Ncm}{ }^{3} \cdot \mathrm{min}^{-1}$; $\mathrm{W}_{\text {(microchannel) }}=300 \mathrm{mg}$ 
Table 1

\begin{tabular}{cccc} 
Catalyst & BET Surface Area & Pore Volume & Average pore diameter \\
& $\mathrm{m}^{2} / \mathrm{g}$ & $\mathrm{cm}^{3} / \mathrm{g}$ & $\AA$ \\
\hline $\mathrm{CuO}_{\mathrm{x}}-\mathrm{CeO}_{2}$ & 75.9 & 0.136 & 74.1 \\
\hline $\mathrm{CuO}_{\mathrm{x}}-\mathrm{CeO}_{2}$ Slurry & 91.6 & 0.200 & 100.0 \\
\hline
\end{tabular}


Table 2

Reducton Zone $\mathrm{H}_{2}$ consumption (mol)

Chemical composition

(mol)

\begin{tabular}{cccc}
\hline A & $1.21 \times 10^{-4}$ & $\mathrm{Cu}$ & $\mathrm{Ce}$ \\
\hline $\mathrm{B}$ & $3.57 \times 10^{-5}$ & $1.00 \times 10^{-4}$ & $2.63 \times 10^{-4}$ \\
\hline
\end{tabular}


Table 3

Joining Post-processing

\begin{tabular}{ccc}
\hline Applied force $(\mathrm{kN})$ & 2.8 & --- \\
\hline Temperature $\left({ }^{\circ} \mathrm{C}\right)$ & 850 & 1200 \\
\hline Heating rate $\left({ }^{\circ} \mathrm{C} \cdot \mathrm{min}^{-1}\right)$ & 100 & \\
\hline Time (minutes) & 40 & 300 \\
\hline Atmosphere & Vacuum & Inert gas \\
\hline
\end{tabular}


Figure 1
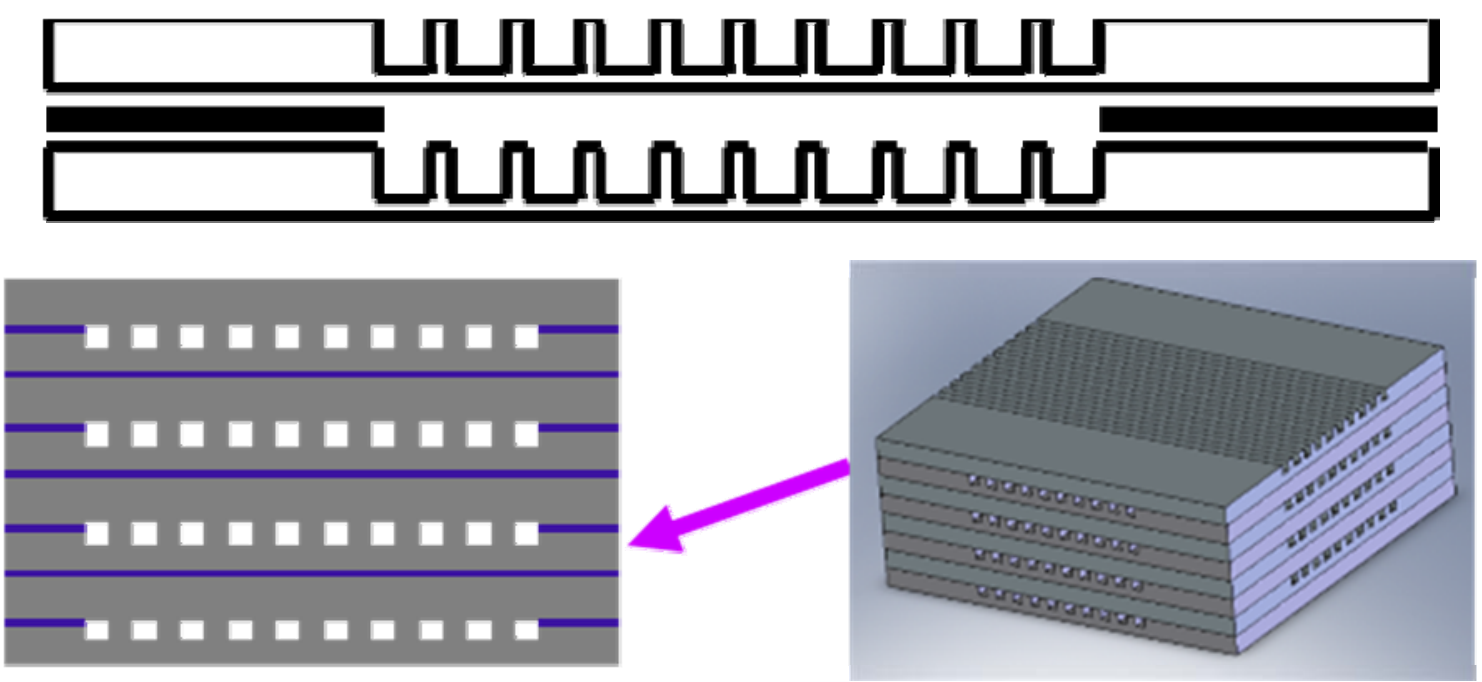
Figure 2

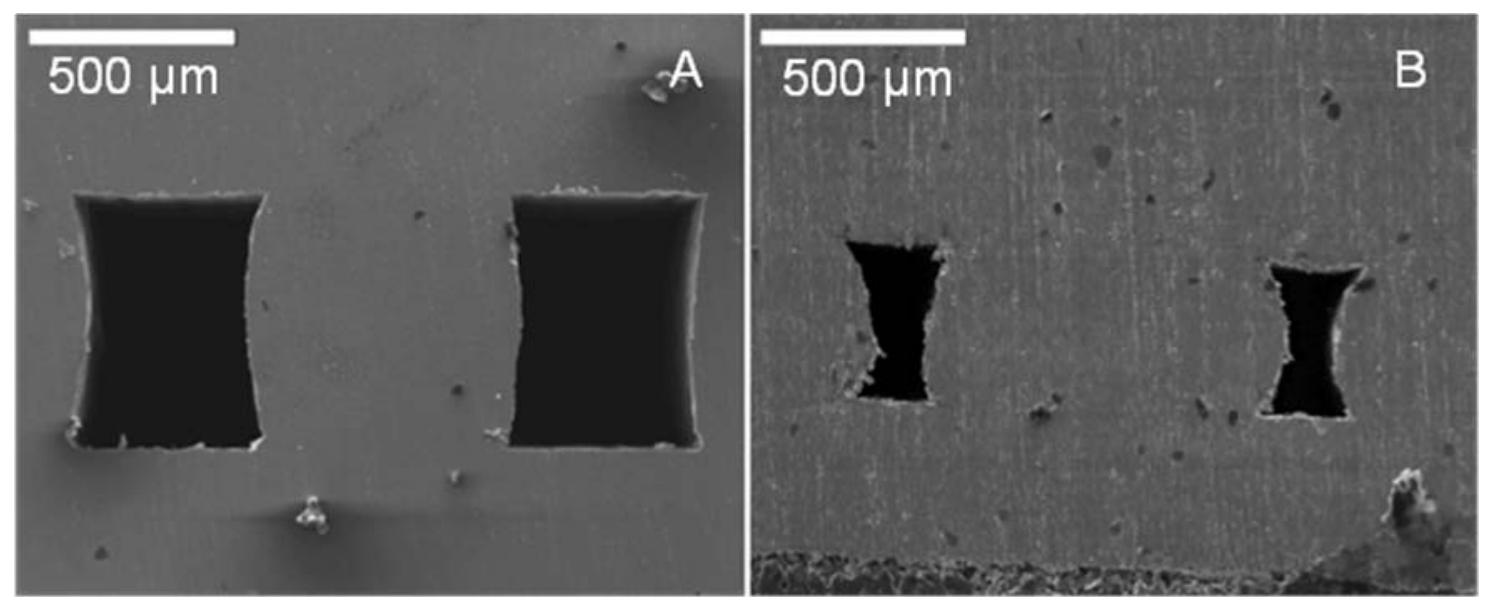


Figure 3
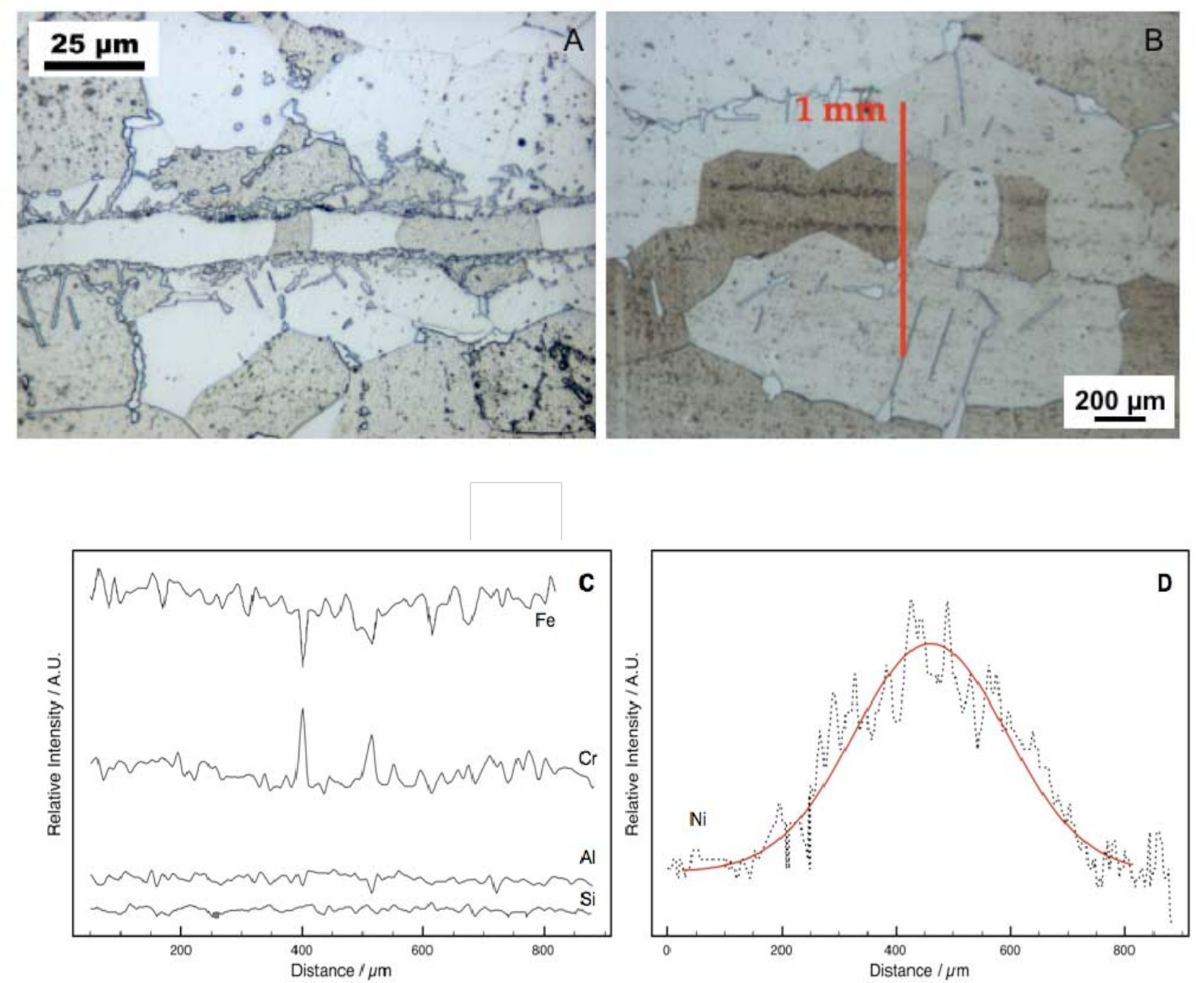
Figure 4
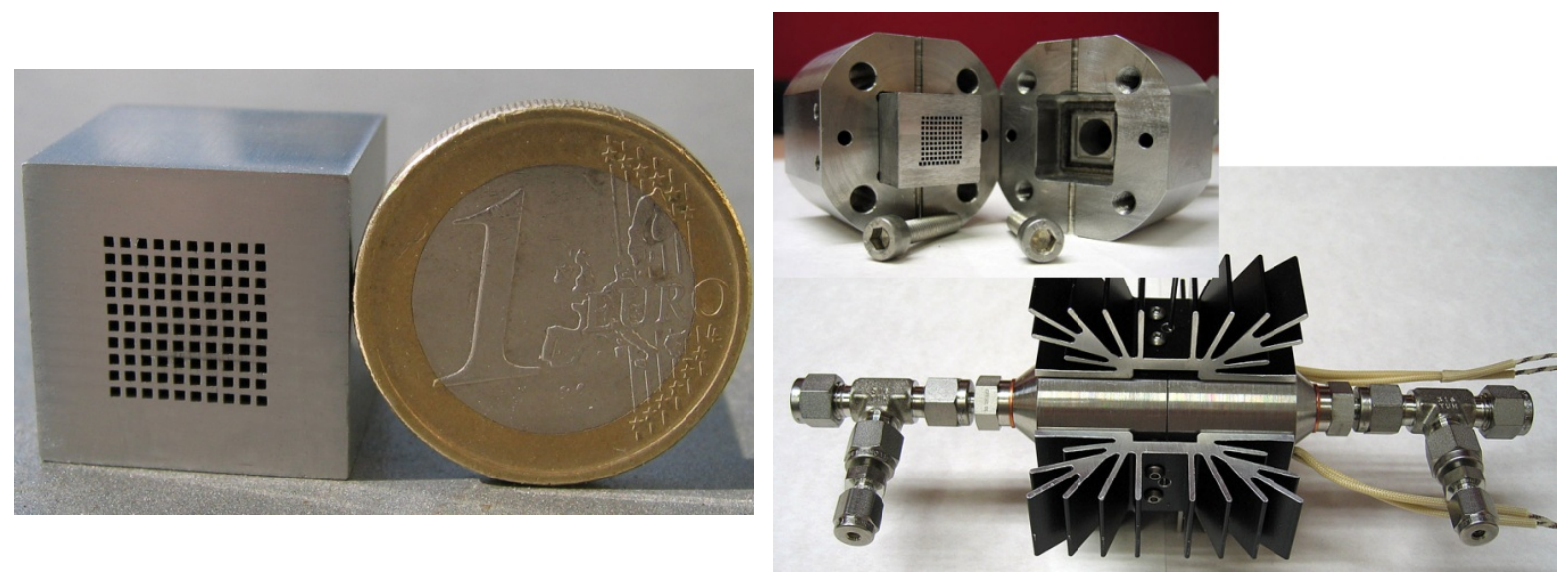
Figure 5

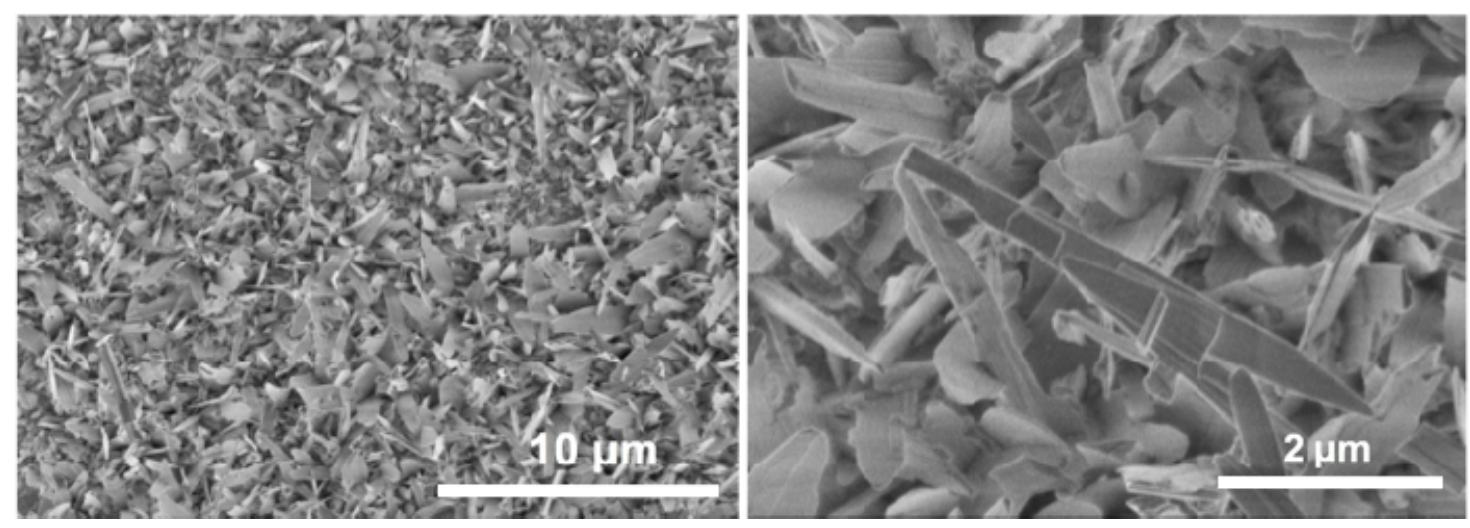


Figure 6

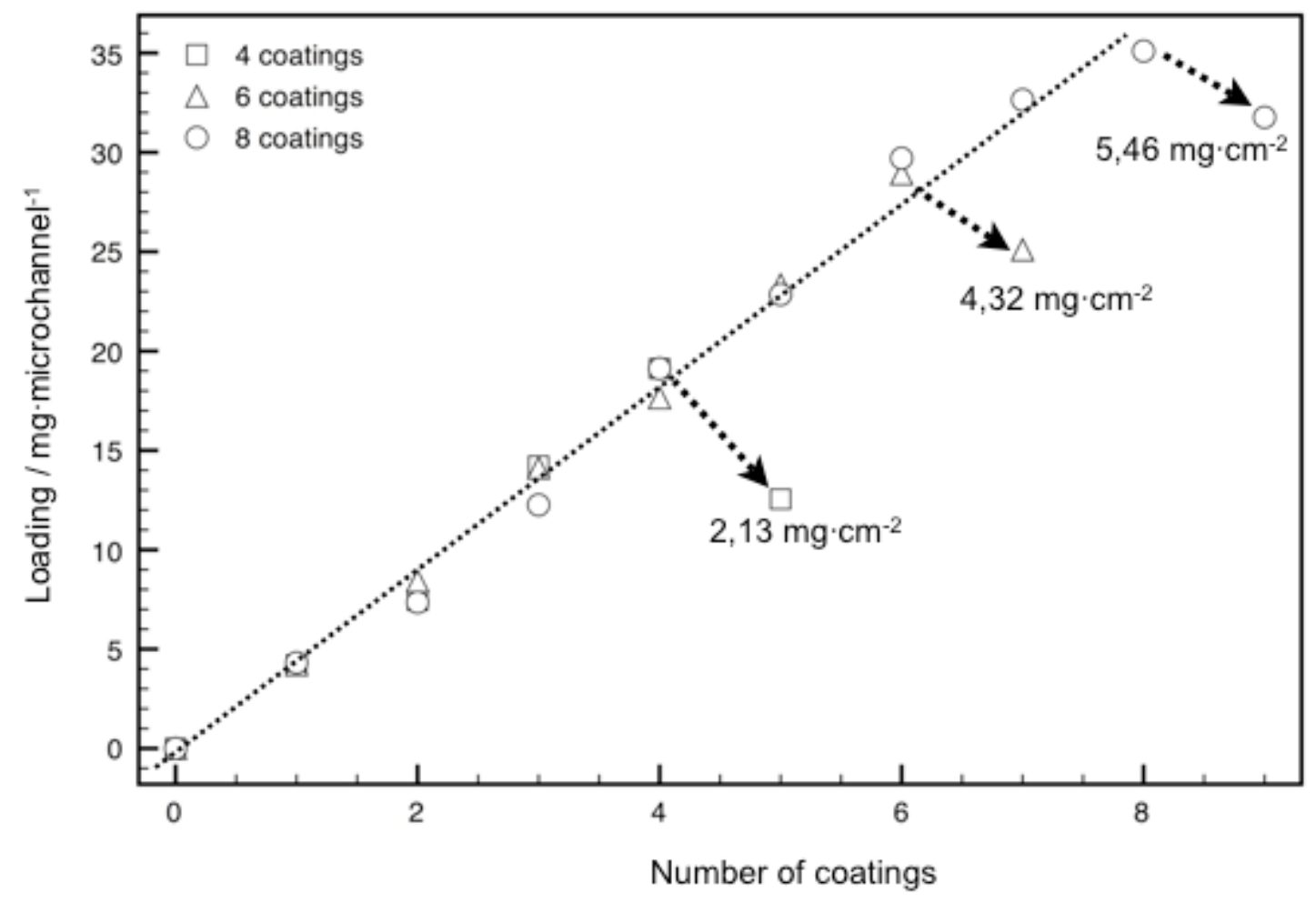


Figure 7

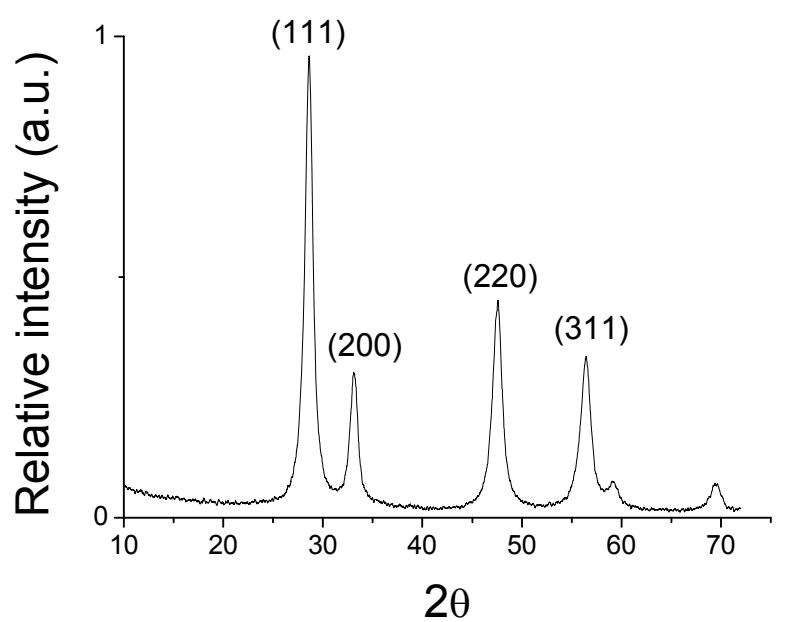


Figure 8

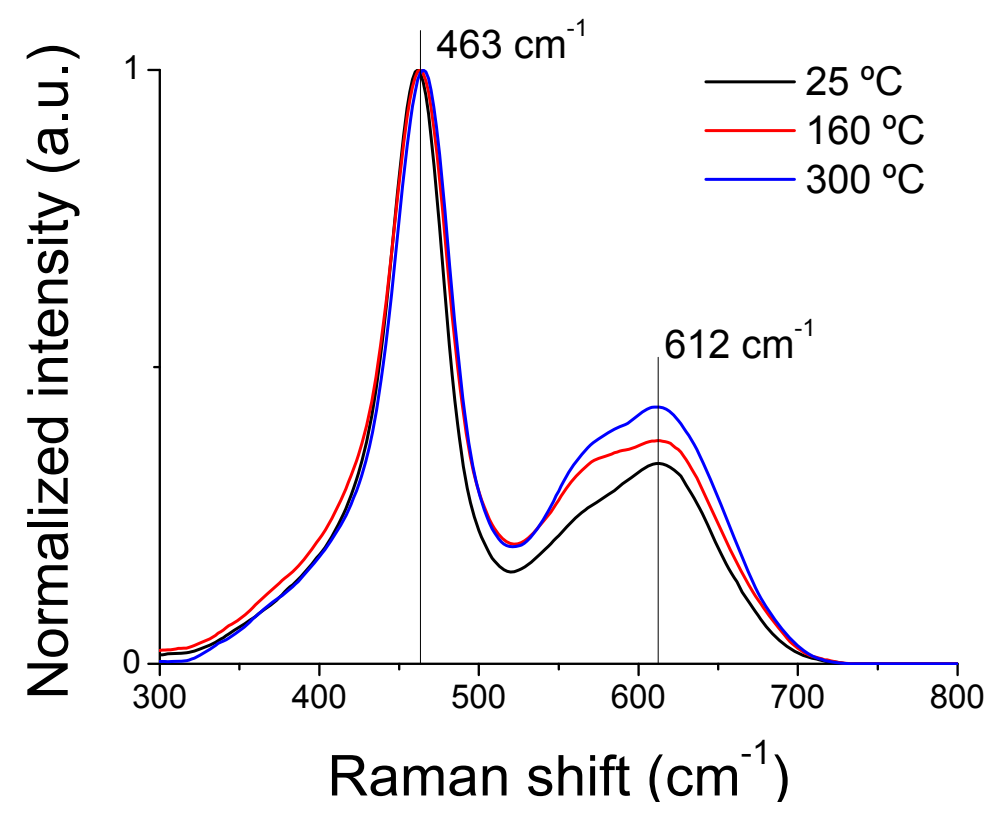


Figure 9

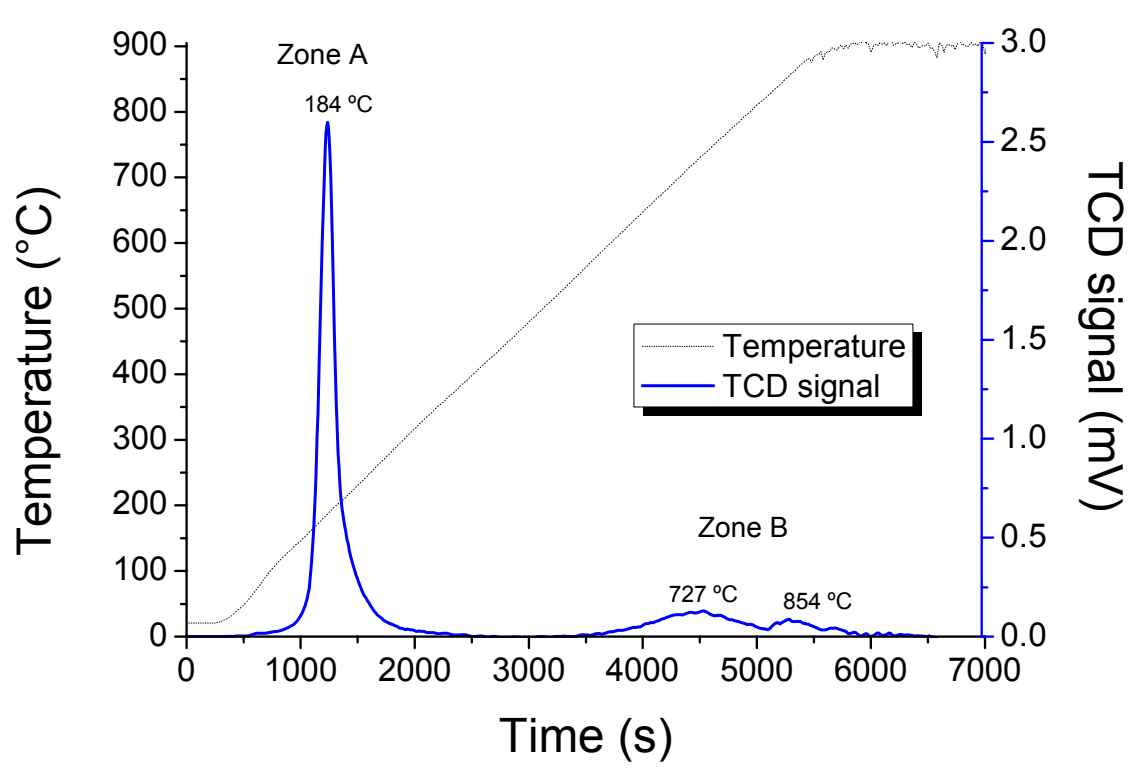


Figure 10
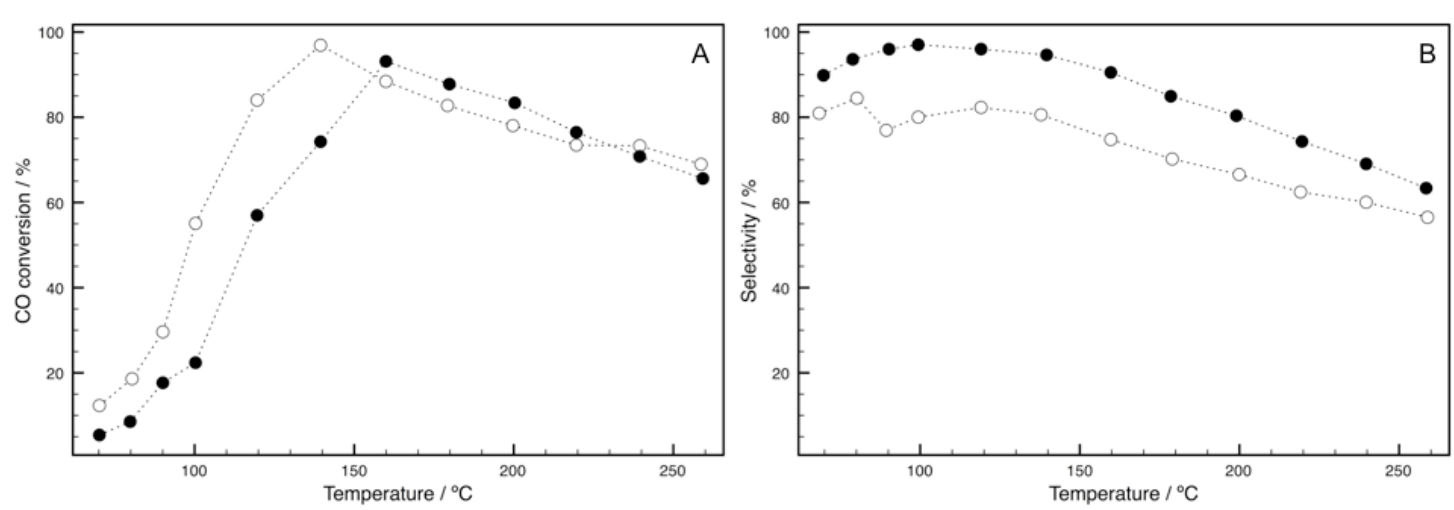
Figure 11
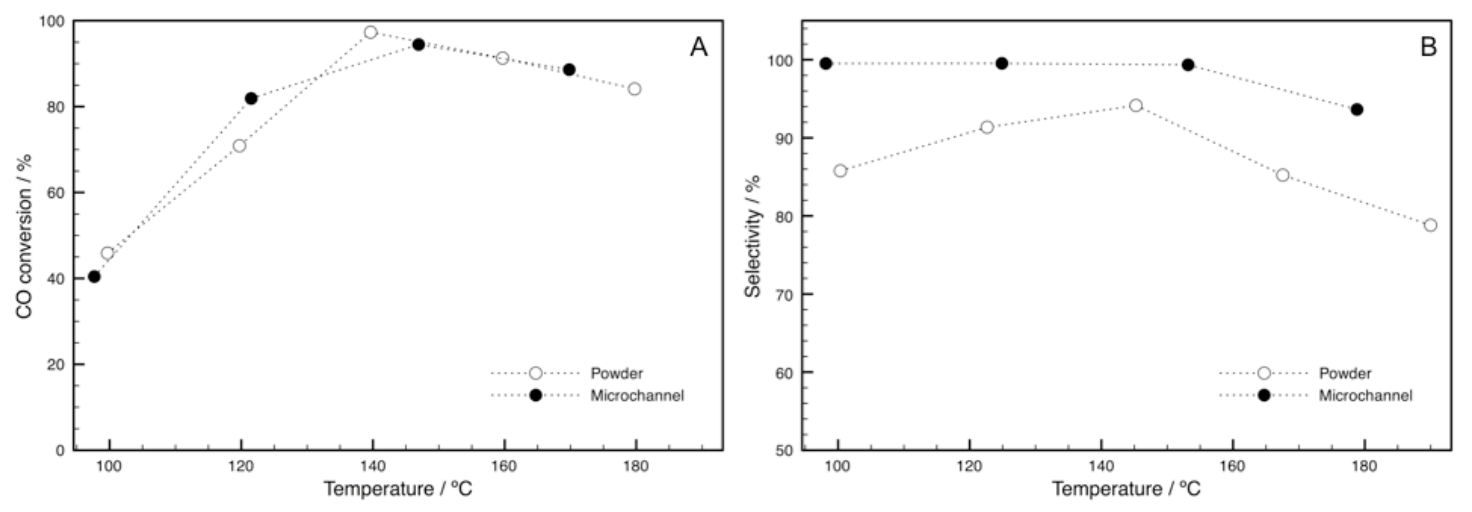
Figure 12

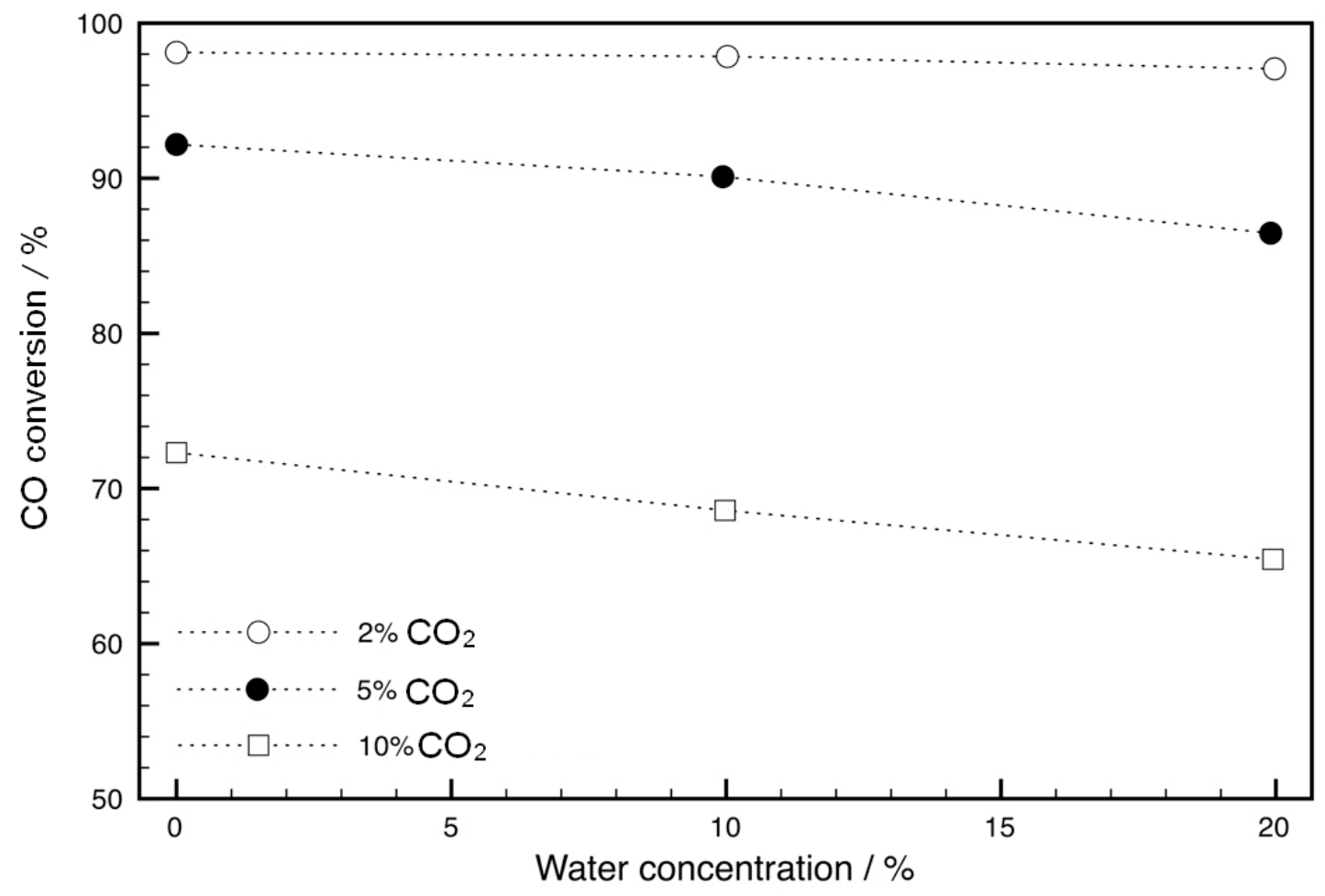

